
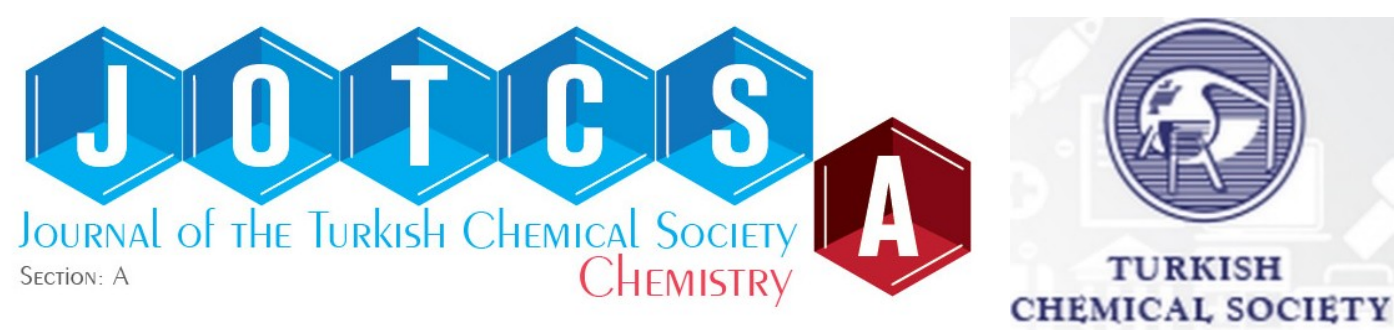

\title{
Antimalarial Evaluation of the Chemical Constituents Isolated from Dendrocalamus asper
}

\author{
Kok Tong Wong ${ }^{1}$, , Hasnah Osman ${ }^{1 *} \triangle$ iD, Thaigarajan Parumasivam² iD, \\ Jafri Malin Abdullah³-5 (D), Mohd. Zaheen Hassan'6 iD, \\ and Mohamad Nurul Azmi ${ }^{1 *}$ iD
}

\begin{abstract}
${ }^{1}$ School of Chemical Sciences, Universiti Sains Malaysia, Minden 11800 Penang, Malaysia
${ }^{2}$ School of Pharmaceutical Sciences, Universiti Sains Malaysia, 11800 Minden, Penang, Malaysia

${ }^{3}$ Department of Neurosciences, School of Medical Sciences, Jalan Hospital USM, 16150 Universiti Sains Malaysia Health Campus, Kota Bharu, Kelantan, Malaysia

${ }^{4}$ Brain and Behaviour Cluster, School of Medical Sciences, Universiti Sains Malaysia Health Campus, 16150, Kota Bharu, Kelantan, Malaysia

${ }^{5}$ Department of Neurosciences \& Brain Behaviour Cluster, Hospital Universiti Sains Malaysia, Universiti Sains Malaysia Health Campus, 16150, Kota Bharu, Kelantan, Malaysia

${ }^{6}$ College of Pharmacy, King Khalid University, Abha, KSA
\end{abstract}

\begin{abstract}
Bamboo shoots of Dendrocalamus asper is essential for human health because of the high content of dietary fiber, low sugar, negligible amount of fat, and rich vitamin and mineral content. The bamboo shoots' chemical constituents were evaluated against the $P$. falciparum strain 3D7 as a potential antimalarial drug. One new metabolite, (11Z,13E,17E,19Z)-dimethyl-15,16-dibutoxytriconta$11,13,17,19$-tetraenedioate (1) along with four known compounds; $\beta$-sitosterol (2), methyl-4hydroxybenzoate (3), 1-methoxy-4-(methoxymethyl)benzene (4) and 4-hydroxybenzaldehyde (5) were isolated from the crude extract of Dendrocalamus asper using chromatographic methods: MPLC, UPLC/MS, analytical and preparative HPLC. Among these, compounds 1, 3, and 4 showed promising antimalarial activity with $\mathrm{IC}_{50}$ between $0.8-2.2 \mu \mathrm{g} / \mathrm{mL}$. The molecular docking between the most potent compound $\mathbf{3}$ and dihydrofolate reductase-thymidylate synthase (DHFR-TS) was done to understand and explore the ligand-receptor interactions and hypothesize the compound's refinements.
\end{abstract}

Keywords: Dendrocalamus asper, antimalarial, P. Falciparum, Molecular docking, dihydrofolate reductase-thymidylate synthase (DHFR-TS).

Submitted: March 28, 2021. Accepted: August 25, 2021.

Cite this: Wong K, Osman H, Parumasivam T, Abdullah J, Hassan M, Azmi M. Antimalarial Evaluation of the Chemical Constituents Isolated from Dendrocalamus asper. JOTCSA. 2021;8(4):995-1002.

DOI: https://doi.org/10.18596/jotcsa.904529.

*Corresponding authors. E-mail: mnazmi@usm.my / ohasnah@yahoo.com

\section{INTRODUCTION}

Malaria is a tropical blood-borne protozoan disease caused by parasites of the genus Plasmodium, and spread by female Anopheles mosquitoes. There are five types of Plasmodium causing malaria viz; $P$. ovale, P. knowlesi, P. malariae, P. vivax, and $P$. falciparum (1). The World Health Organisation
(WHO) reported that in 2018, there were 228 million malaria cases that occurred worldwide. It resulted in 405,000 deaths and approximately $70 \%$ of the global dealths involving children underfive from malaria (2). Even though Malaysia does not have any domestic malaria (indigenous) cases recorded since 2018, it remains one of the most significant health challenges to other southeast 
Asian countries (2). The main drawback of malaria's current treatment are the development of multiple drug resistance and the non-specific targeting to intracellular parasites. This, in turn results in the requirement of high-dose antiparasitic drugs and subsequent intolerable toxicity. Hence, there is a need for novel chemotherapeutic agents.

The tropical rain forest is rich in biological and chemical resources, which have a huge potential as defense agents against pests, diseases, and predators (3). Two natural compounds, quinine, isolated from the stem of Cinchona $s p$. and artemisinin, isolated from the herbal plant Artemisinin annua are phenomenal, and have contributed greatly to reducing deaths due to malaria all over the world $(4,5)$. Malaysia is one of the world's most thriving center of biodiversity with its tropical rainforests. Many of the rainforest plant based phytomedicines are used as an alternative treatment for malaria (6). Among these, the Dendrocalamus asper (bamboo) from the family of Poaceae is a tall arborescent grass, which plays an essential role in construction, reinforcing fibers in paper, medicines, and food sources (7). Bamboo shoots are young, edible plants with health benefits, including healthy weight loss, antibacterial and anti-carcinogenic activities.

To date, no antimalarial studies have been reported on the bamboo plant. Therefore, this research reports new potential antimalarial agents, and phytochemical investigations of the extract from bamboo shoots of Dendrocalamus asper. The evaluation of the antimalarial activity of all the isolated compounds are herein reported.

\section{EXPERIMENTAL SECTION}

\section{Plant material}

Bamboo shoots of Dendrocalamus asper (DAPB52014) were collected at Pos Brook Village, Gua Musang, Kelantan, Malaysia. The bamboo shoots were identified by Assistant Botanist, Mr. Deraman, M., from South Kelantan Development Authority (KESEDAR).

\section{General}

All chemicals were obtained from QRec (Asia) and Merck (Germany). Thin-layer chromatography (TLC) were performed on alumina plates precoated with silica gel (Merck $60 \mathrm{~F}_{254}$ ). The spots were determined under UV radiation $\left(\lambda_{\max }=254\right.$ $\mathrm{nm}$ ). $\mathrm{SiO}_{2}-\mathrm{MPLC}$ was performed using CombiFlash Companion (Teredyne ISCO). Preparative reverse phase HPLC was performed using a Waters 600 pump system with Waters 2998 photodiode array detector and Senshu pack pegasil ODS column (20 X $250 \mathrm{~mm}$ ). Analytical HPLC was performed using an Empower system with Waters 2996 detector with senshu pack column (4.6 X $250 \mathrm{~mm})$ and Waters 717 plus autosampler. One- and twodimensional nuclear magnetic resonance (NMR) spectra were recorded using a JEOL ECA-500 spectrometer at Chemical Biology Building, RIKEN, Wakoshi, Saitama, Japan using $\mathrm{CDCl}_{3}$ and methanol- $d_{4}$ as solvents. Infrared (IR) spectrum was recorded on a Perkin-Elmer System FTIR-ATR spectrometer at the School of Chemical Sciences, USM. The chemical ionization mass spectrometry (CI-MS) was recorded by using a Bruker Micro TOF-QII LCMS at the Department of Chemistry, National University of Singapore. The measurement was carried out in positive-ion mode. Mass resolution: 17,500 (FWHM), temperature compensated, mass range: 50-20,000 $m / z$, acquisition rate: $20 \mathrm{~Hz}$ (2 GHz sampling rate).

\section{Extraction, separation, and isolation}

The dried bamboo shoot $(1.29 \mathrm{~kg})$ was extracted with three different types of solvents, one after the other on the same bamboo shoot. First, $n$-hexane was used in the extraction. After the extraction, the bamboo shot was evaporated to dryness. It was then extracted with dichloromethane. After which the sample was evaporated to dryness and finally extracted with methanol. The recovered extractants were evaporated using a rotary evaporator to obtain the crude extract. The dry weight of $n$-hexane extract (BSH) was $19.4 \mathrm{~g}$, the dichloromethane extract (BSD) was $30.9 \mathrm{~g}$, and the methanol extract (BSM) was $80.9 \mathrm{~g}$. Figure 1 shows the structure of compounds isolated from the $n$-hexane and dichloromethane extracts.

\section{n-hexane extract (BSH)}

$\mathrm{BSH}$ extract $(16.5 \mathrm{~g})$ was separated by $\mathrm{SiO}_{2}$-MPLC eluted with $n$-hexane:acetone stepwise gradient (100:0, 99:1, 98:2, 95:5, 90:10, 80:20, 50:50, $0: 100)$ to obtain 8 fractions. Fr.5 (2.08 g) was subjected to the $\mathrm{SiO}_{2}$-MPLC with $n$-hexane/ethyl acetate gradient system (ethyl acetate: 0-100\%) to afford five fractions (Fr.5.1 to Fr.5.5). Fr.5.4 (200.7 mg/ $432.3 \mathrm{mg}$ ) was subjected to the $\mathrm{SiO}_{2}-$ MPLC using $n$-hexane/ethyl acetate in a stepwise gradient (ethyl acetate $0-100 \%$ ) to afford six fractions (Fr.5.4.1 to Fr.5.4.6). Fr.5.4.5 (18.2 mg) was purified by preparative reverse phase HPLC using an isocratic solvent system of $\mathrm{MeCN} / \mathrm{H}_{2} \mathrm{O}$ $(80 / 20)$ to yield compound $\mathbf{1}\left(t_{R} 12.5 \mathrm{~min}, 2.1 \mathrm{mg}\right.$, $0.013 \%)$ as a yellowish oil.

Further analysis of Fr.5.4.3 afforded compound 2 $(27.0 \mathrm{mg}, 0.164 \%)$ as a white solid. Fr.6 (1.53 g) was subjected to the $\mathrm{SiO}_{2}$-MPLC using hexane/ethyl acetate gradient system (ethyl acetate: $0-100 \%$ ) to afford five fractions (Fr.6.1 to Fr.6.5). Purification of Fr.6.3 (50.5 mg) by preparative reverse phase HPLC using an isocratic 
solvent system of $\mathrm{MeCN} / \mathrm{H}_{2} \mathrm{O}$ (20/80) yielded compound 3 ( $t_{R} 42.1 \mathrm{~min}, 3.9 \mathrm{mg}, 0.024 \%$ ) as a white powder. This fraction also afforded compound 4 ( $t_{R} 21.6 \mathrm{~min}, 3.7 \mathrm{mg}, 0.022 \%$ ) as a white powder through the preparative reverse phase HPLC using an isocratic solvent system of $\mathrm{MeCN} / \mathrm{H}_{2} \mathrm{O}(20 / 80)$.

From spectroscopic analyses, compound $\mathbf{1}$ was found to be a new compound. While compounds 2 , 3 and $\mathbf{4}$ were identified as $\beta$-sitosterol, methyl-4hydroxybenzoate, and 1-methoxy-4(methoxymethyl)benzene, respectively, by comparing with the spectroscopic data in the literature (8-11).

(11Z,13E,17E,19Z)-dimethyl-15,16-

dibutoxytriconta-11,13,17,19-tetraenedioate (1) ( $t_{R} 12.5 \mathrm{~min}, 2.1 \mathrm{mg}, 0.013 \%$ ) as yellowish oil. FTIR (ATR) $V_{\max } \mathrm{cm}^{-1}: 3013\left(\mathrm{C}-\mathrm{H} \mathrm{sp}{ }^{2}\right), 2927$ (C-H $\left.s p^{3}\right), 1712(\mathrm{C}=\mathrm{O}), 1221(\mathrm{C}-\mathrm{O}), 1093(\mathrm{C}-\mathrm{H}$ in plane bending), 751 (C-H out-of-plane bending); $\mathbf{1}_{\mathbf{H}-}$ NMR (500MHz, $\left.\mathbf{C D C l}_{3}\right): \delta_{\mathrm{H}} 0.87(3 \mathrm{H}, \mathrm{t}, \mathrm{J}=6.5$ $\left.\mathrm{Hz}, 4^{\prime}-\mathrm{CH}_{3}\right), 2.15(2 \mathrm{H}, \mathrm{q}, J=5.5 \mathrm{~Hz}$ and $6.9 \mathrm{~Hz}$, $\left.10-\mathrm{CH}_{2}\right), 2.28\left(2 \mathrm{H}, \mathrm{t}, J=7.5 \mathrm{~Hz}, 2-\mathrm{C}_{2}-\underline{\mathrm{H}}\right), 3.62$ $\left(2 \mathrm{H}, \mathrm{s}, 1^{\prime}-\mathrm{OCH}_{2}-\right), 3.64\left(3 \mathrm{H}, \mathrm{s},-\mathrm{OC}_{3}\right), 4.13(1 \mathrm{H}$, $\mathrm{m}, 15-\mathrm{OC} \underline{\mathrm{H}}-), 5.43(1 \mathrm{H}, \mathrm{dt}, \mathrm{J}=6.4 \mathrm{~Hz}$ and 10.9 $\mathrm{Hz}, \mathrm{H}-11), 5.64(1 \mathrm{H}, \mathrm{dd}, J=6.9 \mathrm{~Hz}$ and $15.2 \mathrm{~Hz}$, $\mathrm{H}-14), 5.95(1 \mathrm{H}, \mathrm{t}, \mathrm{J}=11.5 \mathrm{~Hz}, \mathrm{H}-12)$ and 6.46
$(1 \mathrm{H}, \mathrm{dd}, J=10.9 \mathrm{~Hz}$ and $15.5 \mathrm{~Hz}, \mathrm{H}-13) ;{ }^{13} \mathrm{C}-$ NMR (125 MHz, CDCl3); $\delta_{C} 14.3$ (C-4'), 22.8 (C$\left.3^{\prime}\right), 25.1$ (C-3), $25.6(\mathrm{C}-4), 28.0(\mathrm{C}-10), 29.3$ (C5), 29.4 (C-6), 29.5 (C-7), 29.6 (C-8), 31.7 (C-2'), $34.3(\mathrm{C}-2), 37.5(\mathrm{C}-9), 51.7\left(-\mathrm{OCH}_{3}\right), 70.8\left(\mathrm{C}-1^{\prime}\right)$, 73.1 (C-15), 126.1 (C-13), 127.9 (C-12), 133.3 (C-11), 136.0 (C-14), and 174.5 (C-1); CI-MS: $\mathrm{m} / \mathrm{z} 647.4[\mathrm{M}+\mathrm{H}]^{+}$\{calcd 646.5 for $\left.\left(\mathrm{C}_{20} \mathrm{H}_{35} \mathrm{O}_{3}\right)_{2}\right\}$ and $m / z \quad 585.2\left[_{[\mathrm{M}-31]^{+}}\right.$\{calcd 585.9 for $\left.\left(\mathrm{C}_{19} \mathrm{H}_{32} \mathrm{O}_{2}\right)_{2}\right\}$.

\section{Dichloromethane extract (BSD)}

A part of BSD (5.12 g) was separated by $\mathrm{SiO}_{2}-$ MPLC using $\mathrm{CHCl}_{3} / \mathrm{MeOH}$ in a stepwise gradient $\left(\mathrm{CHCl}_{3} / \mathrm{MeOH}\right.$ 100:0, 99:1, 98:2, 95:5, 90:10, $80: 20,50: 50,0: 100)$ to obtain eight fractions. Fr.5 $(414.2 \mathrm{mg})$ was subjected to the $\mathrm{SiO}_{2}$-MPLC with $\mathrm{CHCl}_{3} / \mathrm{MeOH}$ gradient system (methanol: 0-100\%) to afford eight fractions (Fr.5.1 to Fr.5.8). Then, Fr.5.4 (0.414 g/ $2.380 \mathrm{~g})$ was subjected to the $\mathrm{SiO}_{2}$-MPLC using $n$-hexane/EtOAc in a stepwise gradient (EtOAc 0-100\%) to afford eight fractions (Fr.5.4.1 to Fr.5.4.8). TLC analysis of Fr.5.4.3 yielded compound 5 (203.3 $\mathrm{mg}, 3.9707 \%$ ) as a white powder. Based on the spectral data and comparison with the literature report $(12,13)$, compound 5 was identified as 4hydroxybenzaldehyde.

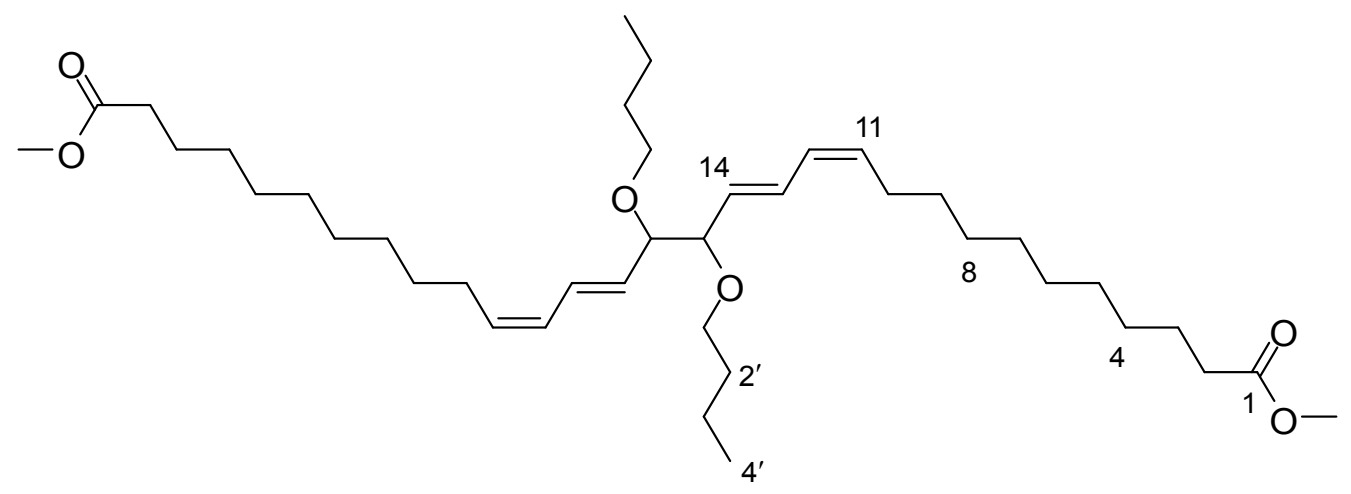

1<smiles>CCC(CC[C@H](C)C1CCC2C3CC=C4C[C@@H](O)CC[C@]4(C)C3CC[C@@]21C)C(C)C</smiles>

2<smiles>COC(=O)c1ccc(O)cc1</smiles><smiles>O=Cc1ccc(O)cc1</smiles>

Figure 1: Compounds 1-5 isolated from Dendrocalamus asper. Compound $\mathbf{1}$ to $\mathbf{4}$ is from the BSH extract and compound $\mathbf{5}$ is from the BSD extract. 


\section{Antimalarial activity}

Plasmodium falciparum 3D7 were cultured at $37^{\circ} \mathrm{C}$ under $5.0 \% \mathrm{CO}_{2}$ an $5 \% \mathrm{O}_{2}$ in $3 \%$ hematocrit t-type A human red blood cells (Japanese Red Cross Society) in RPMI1640 (Thermo Fisher Scientific), supplied with $0.4 \%$ glucose, $20 \mu \mathrm{g} / \mathrm{mL}$ hypoxanthine, $24 \mu \mathrm{g} / \mathrm{mL}$ gentamicin, and $0.25 \%$ AlbuMax-II [14,15]. The, $P$. falciparum growth assay was performed by suspending $100 \mu \mathrm{L}$ of $0.3 \%$-parasitized red blood cells (as above) and $2 \%$ hematocrit in a 96-well plate for $72 \mathrm{~h}$; the plates were frozen overnight at $-70+\mathrm{C}$ and then thawed at room temperature for $4 \mathrm{~h}$. An amount of $150 \mu \mathrm{L}$ of the reaction mixture $(166 \mathrm{mM}$ sodium $L-$ lactate, $166 \mu \mathrm{M} \quad 3$-acetylpyridine adenine dinucleotide, $208 \mu \mathrm{M}$ Nitro Blue Tetrazolium Chloride, $150 \mu \mathrm{g} / \mathrm{mL}$ diaphorase (22.5 U/mL), $0.8 \%$ Tween 20, $116 \mathrm{mM}$ Tris- $\mathrm{HCl}$, $\mathrm{pH} 8.0$ ) was then freshly prepared and added into the wells to analyze LDH activity. After 10 minutes of incubation at room temperature, the plates were shaken to ensure mixing and the absorbance at $650 \mathrm{~nm}$ using a plate reader (PerkinElmer) was recorded.

\section{Molecular docking}

Molecular docking studies were performed using AutoDock v. 4.2.2 to identify appropriate binding modes and conformation of the ligand molecule. The crystal structure of Plasmodium falciparum DHFR-TS complexed with pyrimethamine (PDB code: 3QG2) was retrieved from the RCSB protein data bank as a PDB format (https://www.rcsb.org/structure/3QG2) (16). Preparation of protien was carried out following the steps described elsewhere (17). All hetero atoms and water molecules were deleted using PyMol(version 1.3) software packages whereas, energy minimization of the protein was carried out using Swiss-Pdb viewer software (version 4.1.0). The structures of all the ligands were drawn using Chemdraw Ultra 13.0 and converted into 3D structures using Hyperchem Pro 8.0 software (www.hyper.com). Autodock Tools (ADT) version 1.5.6 (www.autodock.scrips.edu) was used to prepare the molecular docking. The active site was considered as a rigid molecule, while the ligands were treated as being flexible. Finally, rigid docking simulation was performed by AutoDock software considering the center grid box size of $27 \times 6 \times 67$ in the $x, y$ and $z$ coordinates. The best binding con-formation was selected from the docking log (.dlg) file for each ligand and further interaction analysis was done using PyMol and Discovery Studio Visualizer 4.0.

\section{RESULTS AND DISCUSSION}

\section{Chemistry}

Extraction followed by chromatographic fractionation of Dendrocalamus asper yielded one new compound; $(11 Z, 13 E, 17 E, 19 Z)$-dimethyl15,16 -dibutoxytriconta-11,13,17,19-tetraenedioate (1), and four known compounds; $\beta$-sitosterol (2) (18), methyl-4-hydroxybenzoate (3) $(19,20), 1$ methoxy-4-(methoxymethyl)benzene (4) (21) and 4-hydroxybenzaldehyde (5) (22) (Figure 1). The last four known compounds have not been previously isolated from this plant species. The structure of 1 was elucidated by FTIR, 1D and 2D NMR, and CI-MS.

The FTIR of compound $\mathbf{1}$ exhibited transmission bands at 3013, and $2927 \mathrm{~cm}^{-1}$ due to the $\mathrm{C}-\mathrm{H} s p^{2}$ and $\mathrm{C}-\mathrm{H} s p^{3}$ stretching. Besides that, the transmission band at $1712 \mathrm{~cm}^{-1}$ indicated the presence of the carbonyl group $(\mathrm{C}=\mathrm{O})$ stretching of the methylated fatty acid ester moiety attached to compound $\mathbf{1}$. Also, the band at $1221 \mathrm{~cm}^{-1}$ was attributed to the $\mathrm{C}-\mathrm{O}$ bond stretching vibration, while the band at $1093 \mathrm{~cm}^{-1}$ was assigned to the in-plane bending of the $\mathrm{C}-\mathrm{H}$ bond.

The ${ }^{1} \mathrm{H}$ NMR spectrum of compound $\mathbf{1}$ exhibits four signals at $\delta_{\mathrm{H}} 6.46 \mathrm{ppm}(1 \mathrm{H}, \mathrm{dd}, J=10.9 \mathrm{~Hz}$ and $15.5 \mathrm{~Hz}), 5.95 \mathrm{ppm}(1 \mathrm{H}, \mathrm{t}, \mathrm{J}=11.5 \mathrm{~Hz}), 5.64 \mathrm{ppm}$ $(1 \mathrm{H}, \mathrm{dd}, J=6.9 \mathrm{~Hz}$ and $15.2 \mathrm{~Hz}), 5.43 \mathrm{ppm}(1 \mathrm{H}$, $\mathrm{dt}, J=7.5 \mathrm{~Hz}$ and $10.9 \mathrm{~Hz}$ ) which represents the four vinylic protons, $\mathrm{H}-13, \mathrm{H}-12, \mathrm{H}-14$, and $\mathrm{H}-11$. $\mathrm{H}-11$ and $\mathrm{H}-14$ protons are bonded to an $s p^{3}$ hybridized carbon, C-10, and C-15, respectively. So, they are shielded and absorb upfield compared to $\mathrm{H}-12$ and $\mathrm{H}-13$. $\mathrm{H}-13$ has two nearby nonequivalent protons that split its signal, the trans protons of $\mathrm{H}-12$ and $\mathrm{H}-14$. $\mathrm{H}-14$ splits the $\mathrm{H}-13$ signal into a doublet, and $\mathrm{H}-12$ proton splits the doublet into two doublets, forming doublet of the doublet. At the same time, $\mathrm{H}-12$ has two nearby non-equivalent protons, the cis proton $\mathrm{H}-11$, and trans proton $\mathrm{H}-13 . \mathrm{H}-13$ is more deshielded than $\mathrm{H}-12$ due to the hydrogen in a cis-isomer being slightly more upfield and trans hydrogen being more downfield to the left of the spectrum. Two singlet signals located at $\delta_{H} 3.64(3 \mathrm{H})$ and $\delta_{H} 3.62$ $(2 \mathrm{H})$ were assigned to the $-\mathrm{OC}_{3} \underline{H}_{3}$ and $1^{\prime}-\mathrm{OC}_{2}$. The ${ }^{13} \mathrm{C}$ NMR of compound $\mathbf{1}$ shows the presence of 20 signals. The signals for twelve methylene carbons (C-2, C-3, C-4, C-5, C-6, C-7, C-8, C-9, C-10, C$1^{\prime}, C-2^{\prime}$, and $\left.C-3^{\prime}\right)$ can be observed at $\delta_{C} 34.3$, $25.1,25.6,29.3,29.4,29.5,29.6,37.5,28.0$, $70.8,31.7$, and 22.8, respectively. Meanwhile, the signal for carbonyl carbon, C-1 showed a resonance at $\delta_{\mathrm{C}} 174.5$. The ${ }^{1} \mathrm{H}-{ }^{1} \mathrm{H}$ COSY and HMBC correlations of compound $\mathbf{1}$ are shown in Figure $\mathbf{2}$. The HMBC spectrum reveals the aliphatic proton, $\mathrm{H}-14$ at $\delta_{\mathrm{H}} 5.64$, correlated with $\mathrm{C}-12$ ( $\left.\delta_{\mathrm{C}} 127.9\right)$ and $\mathrm{C}-15\left(\delta_{\mathrm{C}} 73.1\right)$. The signal for methyl proton $\left(4^{\prime}-\mathrm{C}_{3}{ }_{3}\right)$ showed cross-peak with $\mathrm{C}-2^{\prime}$ ( $\delta_{\mathrm{c}} 31.7$ ) 
and $\mathrm{C}-3^{\prime}\left(\delta_{\mathrm{C}} 22.8\right)$. Besides, the singlet methoxy proton $\left(-\mathrm{OC}_{3} \underline{3}\right)$ at $\delta_{\mathrm{H}} 3.64$ assigned to $-\mathrm{OCH}_{3}\left(\delta_{\mathrm{C}}\right.$
51.7) showed HMBC correction with the carbonyl carbon, C-1 ( $\delta_{c}$ 174.5).

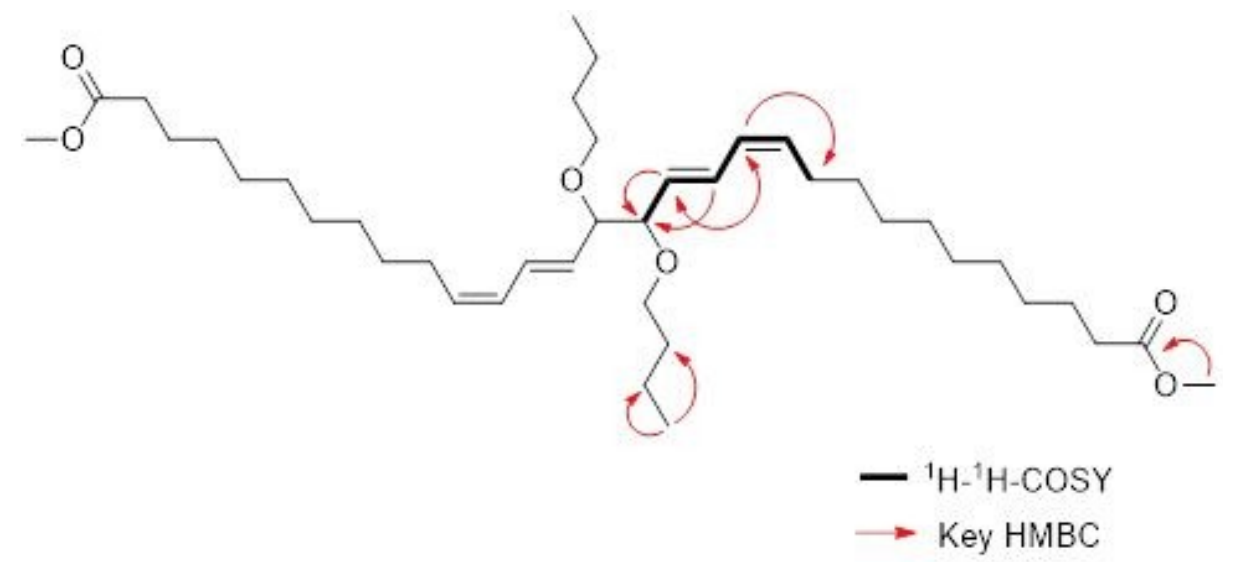

Figure 3. Key COSY/ HMBC correlations of compound $\mathbf{1}$.

The nominal APCI-MS spectra of compound $\mathbf{1}$ were in good agreement with the molecular formula $\left(\mathrm{C}_{20} \mathrm{H}_{35} \mathrm{O}_{3}\right)_{2}$ showing a base peak at $\mathrm{m} / \mathrm{z} 646.4$ $[\mathrm{M}+\mathrm{H}]^{+}$\{calcd 646.5 for $\left.\left(\mathrm{C}_{20} \mathrm{H}_{35} \mathrm{O}_{3}\right)_{2}\right\}$. The ion peak at $m / z 585.6$ arise due to the $\left(\mathrm{C}_{19} \mathrm{H}_{32} \mathrm{O}_{2}\right)_{2}$ fragment, by the loss of two methoxy radicals
$[\mathrm{M}+\mathrm{H}-62]^{+} \quad$ (Figure 3). Based on the spectroscopy data (IR, 1D- and 2D-NMR) and mass spectrometric data, compound $\mathbf{1}$ is a new diester isolated for the first time from the plant and its chemical name is $(11 Z, 13 E, 17 E, 19 Z)$-dimethyl15,16-dibutoxytriconta-11,13,17,19tetraenedioate.
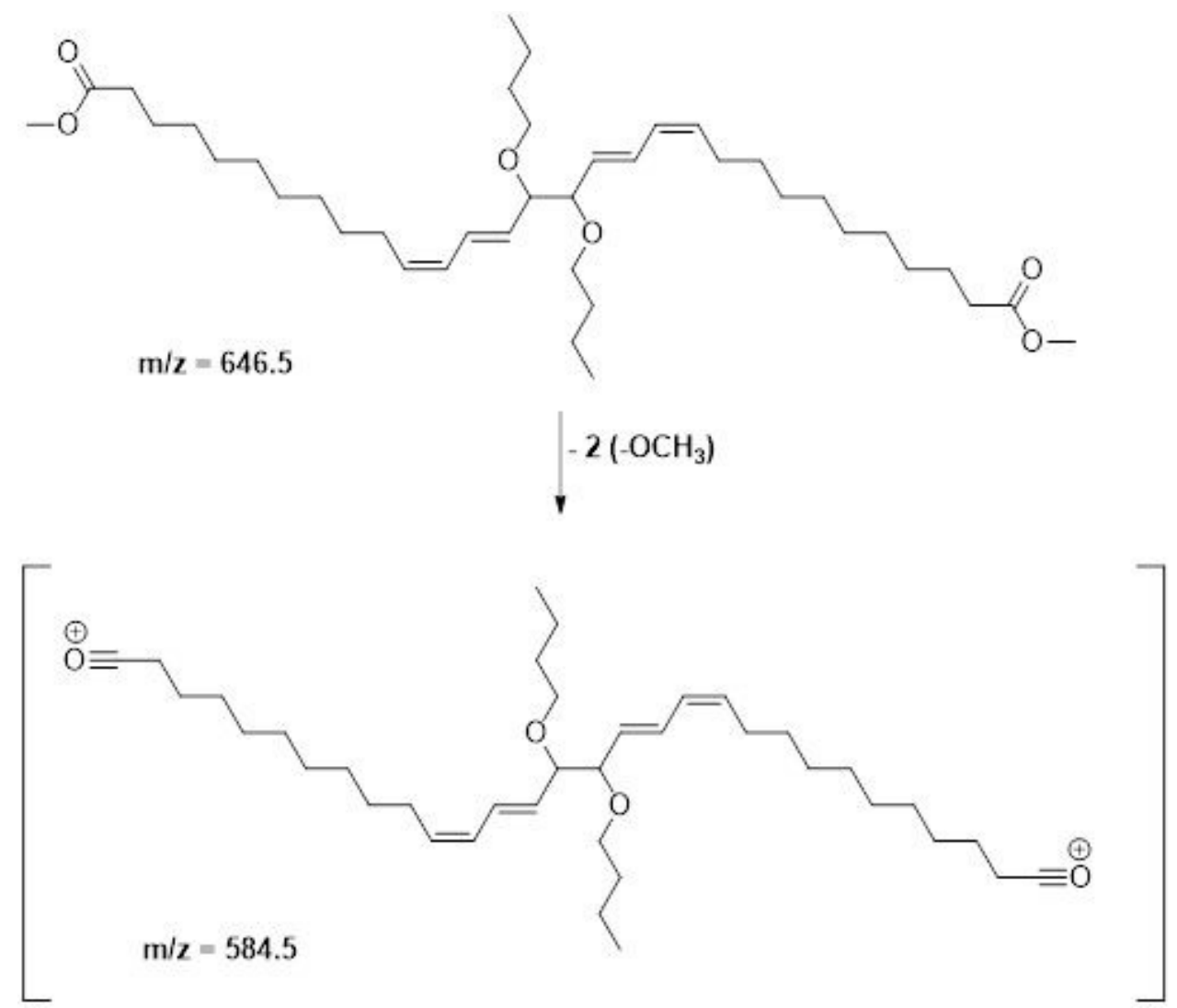

Figure 3. The fragmentation of compound $\mathbf{1}$ leading to the ion peak $\mathrm{m} / \mathrm{z} 584.5$.

\section{Antimalarial activity}

All the five isolated chemical constituents of Dendrocalamus asper were evaluated for their potential antimalarial properties against the $P$. falciparum strain 3D7 (Table 2). Compound $\mathbf{3}$ was the most active compound against the $P$. 
falciparum with the $\mathrm{IC}_{50}$ value of $5 \mu \mathrm{M}(\sim 0.82$ $\mu \mathrm{g} / \mathrm{mL}$ ). Meanwhile, compounds 1 and 4 showed moderate antimalarial activity with the $\mathrm{IC}_{50}$ values of $3 \mu \mathrm{M}(\sim 2.2 \mu \mathrm{g} / \mathrm{mL})$ and $7 \mu \mathrm{M}(\sim 1.1 \mu \mathrm{g} / \mathrm{mL})$, respectively. However, compounds $\mathbf{2}$ and $\mathbf{5}$ showed weak antimalarial activity with $50 \%$ inhibition $\left(\mathrm{IC}_{50}\right)$ value $>24 \mu \mathrm{M}(>10 \mu \mathrm{g} / \mathrm{mL})$ and $>$ $82 \mu \mathrm{M}(>10 \mu \mathrm{g} / \mathrm{mL})$, respectively.

Table 2. Growth inhibitory activity of compounds 1-5 against $P$. falciparum 3D7.

\begin{tabular}{ccc}
\hline Compound & $\boldsymbol{\mu g} / \mathbf{m L}$ & $\mathbf{I} \mathbf{C}_{\mathbf{5 0}}$ \\
& 2.2 & $\boldsymbol{\mu M}$ \\
$\mathbf{1}$ & $>10$ & 3 \\
$\mathbf{2}$ & 0.8 & $>24$ \\
$\mathbf{3}$ & 1.1 & 5 \\
$\mathbf{4}$ & $>10$ & 7 \\
$\mathbf{5}$ & 0.01 & $>82$ \\
Chloroquine (control) & 0.05 \\
\hline
\end{tabular}

Results are mean values of duplicate independent assays

\section{Molecular docking studies}

To gain further evidence regarding the mode of action of the potent compounds (i.e 1, $\mathbf{3}$ and $\mathbf{4}$ ) a molecular docking study was carried out on $P$. falciparum enzyme dihydrofolate reductasethymidylate synthase (DHFR-TS), which is a potential drug target for malaria (16). All the three compounds $1(-4.20 \mathrm{kcal} / \mathrm{mol}), 3(-5.4 \mathrm{kcal} / \mathrm{mol})$, and $4(-5.2 \mathrm{kcal} / \mathrm{mol})$ showed good interactions with the enzyme DHFR-TS in terms of binding interactions. It was also observed that all the three compounds $\mathbf{1}, \mathbf{3}$, and $\mathbf{4}$ occupied the same binding site and formed similar type of interactions with the active site residues (Figure 4 ). The results of binding studies of the most active compound $\mathbf{3}$ clearly indicate that the compound exhibited significant interactions at the active site by forming two hydrogen bonds with LEU164 and TYR170 residues (docking score of $-4.16 \mathrm{kcal} / \mathrm{mol}$ ). A $\Pi-\Pi$ stacking was also observed between the phenyl ring of compound $\mathbf{3}$ and PHE58. The results of molecular docking studies revealed that the antimalarial activity of compound 1, 3 and $\mathbf{4}$ might be due to DHFR-TS inhibition.

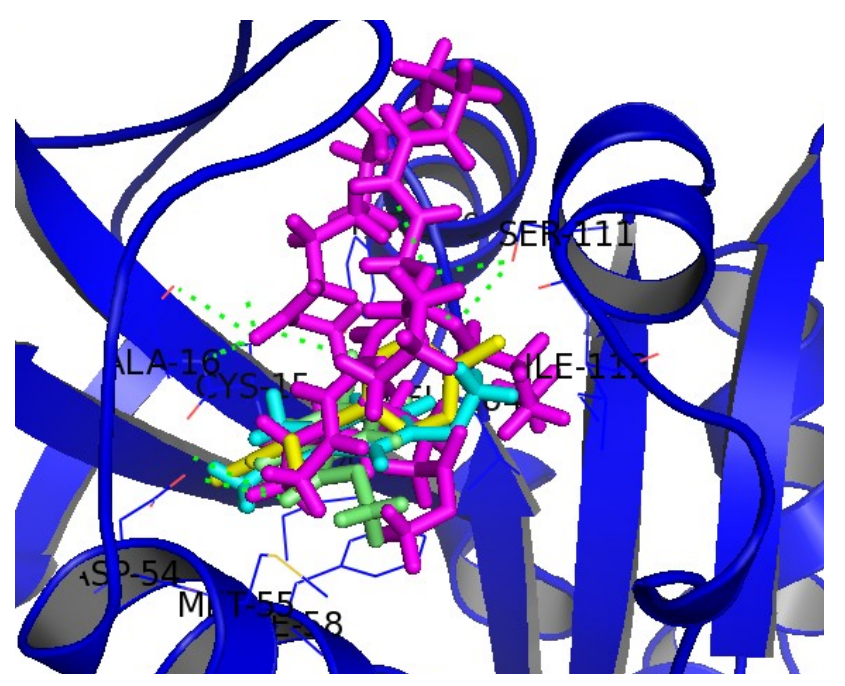

(a)

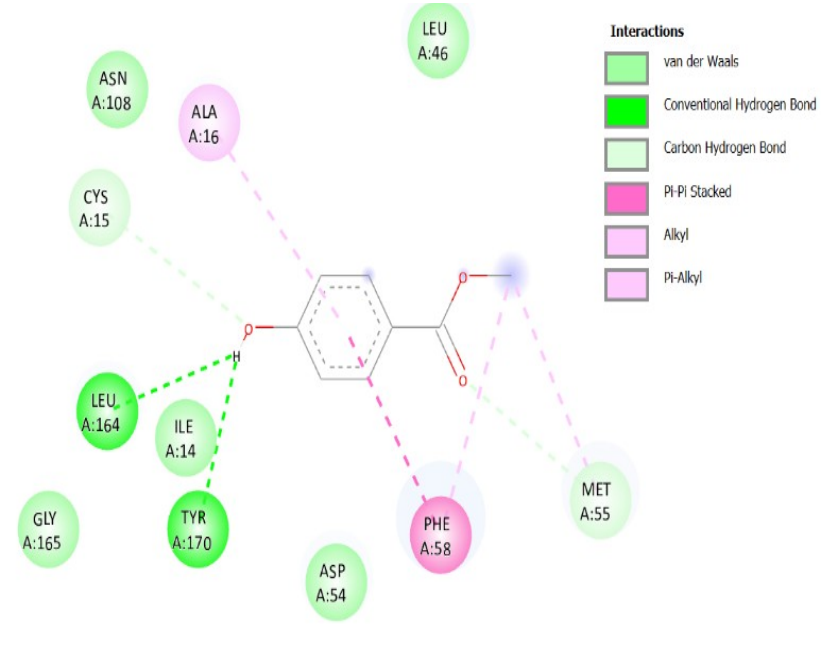

(b)

Figure 4. (a) Docking poses of compound 1 (magenta), 3 (lime), 4 (cyan) and reference ligand pyrimethamine (yellow) at the active site of $P$. Falciparum DHFR-TS (PDB ID: 3QG2) showing hydrogen bondings (green). (b) 2D binding interactions of the most active compound $\mathbf{3}$ showing two hydrogen bonds (green) with LEU164 and TYR170 residues at the active site.

\section{CONCLUSION}

Five bioactive principles were isolated from bamboo shoot extracts, of which one new metabolite, compound $\mathbf{1}$, and three known metabolites, which are compounds 2-4 were isolated from $n$-hexane extract, whereas one known metabolite, compound $\mathbf{5}$ was obtained from dichloromethane extract. Among these, compound $\mathbf{3}$ was highly active against $P$. falciparum with $\mathrm{IC}_{50}$ value of $0.82 \mu \mathrm{g} / \mathrm{mL}$. 


\section{ACKNOWLEDGMENT}

The authors would like to acknowledge the financial support from the Ministry of Higher Education of Malaysia (MyPhD - MyBrain15) and the USM RUT grant (1001/Pkimia/8011072). Wong, K.T. also extends his appreciation to Prof Osada, H., Nogawa, T., and Futamura, Y. from Chemical Biology Research Group, RIKEN Center for Sustainable Resource Science, Wako, Saitama, Japan for providing laboratory facilities and technical assistance under short-term International Program Associate (IPA). We also like to thank Zhang J.L. for his contribution to this project. We also like to thank Awang, K. for the assistance in the confirmation of spectroscopic analysis \& interpretation.

\section{REFERENCES}

1 Al-Adhroey AH, Nor ZM, Al-Mekhlafi HM, Amran AA, Mahmud R. Antimalarial activity of methanolic leaf extract of Piper betle L. Molecules. 2010; 16(1): 107-18. <DOI>.

2. World Health Organisation. 2019 World Malaria Report. Geneva, Switzerland: WHO, 2019. (Accessed 01.03.2020). $\leq U R L>$.

3. Jantan I. Medicinal plant research in Malaysia: Scientific interests and advances. Malaysian J. Health Sci. 2004; 2(2):27-46.

4. Schwikkard S, Van Heerden F. Antimalarial activity of plant metabolites. Nat. Prod. Rep. 2002; 19(6): 675-92. $\leq$ URL $>$.

5. Klayman DL. Qinghaosu (artemisinin): an antimalarial drug from China. Science. 1985; 228(4703): 1049-55. <DOI>.

6. Nik Abdul Rahman NN, Furuta T, Kojima S, Takane K, Mohd MA. Antimalarial activity of extracts of Malaysian medicinal plants. $J$. Ethopharmacol. 1999; 64(3): 249-54. <DOI>.

7. Kant P. Should bamboos and palms be included in CDM forestry projects? IGREC working paper, No. IGREC-07:2010, Institute of Green Economy, New Delhi, 2010. $\leq$ URL $>$.

8. Chaturvedula VSP, Prakash I. Isolation of stigmasterol and $\beta$-sitosterol from the dichloromethane extract of Rubus suavissimus. Int. Curr. Pharm. J. 2012; 1(9): 239-42. <DOI>.

9. Aliba MO, Ndukwe IG, Ibrahim $\mathrm{H}$. Isolation and characterization of $\beta$-sitosterol from methanol extracts of the stem bark of large-leaved rock fig
(Ficus Abutilifolia Miq). J. Appl. Sci. Environ. Manage. 2018; 22(10): 1639-42. <DOI>.

10. Chang YC, Chang FR, Wu YC. The constituents of Lindera glauca. J. Chin. Chem. Soc. 2000; 47(2): 373-80. <DOI>.

11. Bhaskar G, Solomon M, Babu G, Muralidharan D, Perumal PT. A simple and an efficient indium trichloride catalyzed benzyl etherification. Indian J. Chem., Sect B. 2010; 49B: 795-801. $\leq$ URL $>$.

12. Panyo J, Matsunami K, Panichayupakaranant P. Bioassay-guided isolation and evaluation of antimicrobial compound from Ixora megalophylla against some oral pathogens. Pharm. Biol. 2016; 54(9): 1522-27. <DOI>.

13. Magano J, Chen MH, Clark JD, Nussbaumer T. 2-(Diethylamino)ethanethiol, a new reagent for the odorless deprotection of aromatic methyl ethers. J. Org. Chem. 2006; 71(18): 7103-5. $<$ DOI $>$.

14. Hayase $\mathrm{H}$, Watanabe $\mathrm{N}$, Lim $\mathrm{CL}$, Nogawa $\mathrm{T}$, Komatsuya K, Kita $\mathrm{K}$, Osada $\mathrm{H}$. Inhibition of Malaria Parasite Growth by Quinomycin A and its derivatives through DNA-Intercalating Activity. Biosci, Biotechnol, Biochem. 2015; 79(4): 633-5. $\leq \mathrm{DOI}>$.

15. Gamo FJ, Sanz LM, Vidal J, De Cozar C, Alvarez E, Lavandera JL, Vanderwall DE, Green DV, Kumar V, Hasan S, Brown JR, Peishoff CE, Cardon LR, Garcia-Bustos JF. Thousands of chemical starting points for antimalarial lead identification. Nature. 2010; 465(7296): 305-10. <DOI>.

16. Vanichtanankul J, Taweechai S, Yuvaniyama J, Vilaivan T, P Chitnumsub, Kamchonwongpaisan S, Yuthavong Y. Trypanosomal Dihydrofolate Reductase Reveals Natural Antifolate Resistance. ACS. Chem. Biol. 2011; 6(9): 905-11. <DOl .

17. Matin MM, Hasan MS, Uzzaman M, Bhuiyan $\mathrm{MMH}$, Kibria SM, Hossain ME, Roshid MHO. Synthesis, spectroscopic characterization, molecular docking, and ADMET studies of mannopyranoside esters as antimicrobial agents. J. Mol. Struct. 2020; 1222, 128821-33. <DOI>.

18. Ahmad F, Ali M, Alam P. New phytoconstituents from the stem bark of Tinospora cordifolia Miers. Nat. Prod. Res. 2010;24(10): 92634. $\leq \mathrm{DOI}>$.

19. Tian JK, Sun F, Cheng YY. Chemical constituents from the roots of Ranunculus 
ternatus. J. Asian Nat. Prod. Res. 2006; 8(1-2): 35-9. $\leq \mathrm{DOI}>$.

20. Vijayan N. Structural and optical characterization on solution grown methyl p-hydroxybenzoate single crystals. Indian $J$. Chem., Sect A. 2007; 46(1): 70-3. <URL>.

21. Tsai $C Y$, Sung $R$, Zhuang $B R$, Sung $K S$. $\mathrm{TiCl} 4$-activated selective nucleophilic substitution of tert-butyl alcohol and benzyl alcohol with pdonating substituents. Tetrahedron. 2010; 66(34): 6869-72. $\leq \mathrm{DOI}>$.

22. Kim H, Ralph J, Lu F, Boudet AM, MacKay J], Sederoff RR, Ito T, Kawai S, Ohashi H, Higuchi T. NMR analysis of lignins in CAD-deficient plants. Part 1. Incorporation of hydroxycinnamaldehydes and hydroxybenzaldehydes into lignins. Org. Biomol. Chem. 2003; 1(2): 268-81. <DOl>. 